\title{
Coliform Bacteria, Non-Lactose Fermenting
}

National Cancer Institute

\section{Source}

National Cancer Institute. Coliform Bacteria, Non-Lactose Fermenting. NCI Thesaurus.

Code C122268.

Any rod-shaped, gram-negative, non-spore forming bacteria that is incapable of fermenting lactose to produce acid and gas. 